\title{
José contra o medo
}

José Bento Machado Ferreira

Agora, José vai lutar contra o medo, mas não tem lança

e o medo cospe os dedos de José na lama.

Agora, o medo é onça

e as pintas são diamante.

Quem pintou no pêlo dela

estas pedrinhas de brilhante?

José despe as chagas

da cabeça aos pés,

nem as armas de Jorge

nem a luz nem a espada

nem mesmo um dedo que lhe aponte

o descanso.

E agora o medo é a palma da mão que José aperta de vez em quando. 
Onde estão seus companheiros?

Cavalgam terras distantes.

Metem-se entre espinhos.

Quando não caem, mancam.

José atira flechas no peito do medo, agora que tem um arco tamanho, e o medo arranca as flechas do peito como se fossem de brinquedo e sonho,

mastiga cada uma delas com seus dentes de partir pedreiras e abocanhar montanhas.

Quantos dias e noites ainda agüentará José?

Quantos dias houver fumaça.

Quantas noites houver fogueira.

Nem uma semana.

Agora, o medo tem farda, fuzil, carranca e já passeia pelo campo onde José desanda.

Agora não dura um instante. 